して直線的に上昇し，第 1 四のB領域にいたると直線か らずれてつい比定常電位に到達する。

2. 雷位と皮膜厚との間の直線関係加判断して皮膜 内のイオン移動は濃度傾斜に上る拡散ではなく，文膜内 の高い電場によって進行すると考えられる.

3. 種々つ大きさの一定電流住応する電位一皮膜厚 直線は一点に交り，この交点から従来不明瞭であった二 ッケルの Flade 電位の值を推定することができた。 $1 \mathrm{~N} \mathrm{H}_{2} \mathrm{SO}_{4}$ 中 $40^{\circ} \mathrm{C}$ に沏けるニッケルの Flade 電位は +0.435 V であった.

4. 不動態より電流を切った際の放電曲線には，鉄の 場合程明瞅でないが +0.4〜+0.45V 附近にわずかな 電位停滞方みられる.この種の放電曲線は試料の表面状 態によってかなり変化するので，この方法で皮膜の平衡 電位を推定する際には他の方法を立战して比較梌行する 必要がある。

(昭 $33-10-1$ 受理)

\section{文 献}

(1) U.F. Franck, K. Weil; Z. Elektrochem. Ber. Bunsenges. physik. Chem., 5f, 814 (1952)

(2) K.G. Weil: Z. Elektrochem. Ber. Bunsenges. physik. Chem. 59, 711 (1955)
(3) F. Flade: Z. physik. Chem-, 76, 513 (1911); F. Flade \& H. Koch: Z. physik. Chem., 88, 307 (1914)

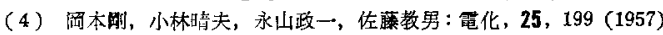

(5) G. Okamoto, H. Kobayashi, M. Nagayama, N. Sato: Z. Elektrochem. Ber. Bunsenges. physik. Chem., 62, 775 (1958)

(6) 前田正婎：電化, 26, 610 (1958)

(7) E. Hourdermont: Handbuch der Sonderstahlkunde I p. 736 774. (1957)

(8) G. Trümpler, H. Meyer; Helv. Chim. Acta., 35, 1304 (1952), 36, 1630 (1953), 39, 1733 (1956)

(9) D.R. Turner: $J$. Elect achem. Soc., 98, 434 (1951)

(10) W. Katz: Z. Metallkunde, 44, 108 (1953)

(11) N.W. Herzog: Eidgenössischen Technishen Hochschule in Zurich. Prom. No 2671 (1957)

(12) H.J. Engell, K. Hanffe: Z. Elektrochem. Ben. Bunsenges. physik. Chem., 57, 762 (1953)

(13) N. Cabrerra, N.F. Mott: Rep. on Prog. Physics, 163 (1949)

(14) A. Gunther-Schulz, \& H. Betz: Z. physik., 78, 210 (1932)

(15) O. Flint, J.J. Polling, A. Charlsby : Acta Metallur gi$\mathrm{ca}, 2,696(1954)$

(16) 前田正雄：電化，25，195（1957）

(17) H.J. Engell, B. Ilschner: Z. Elektrochem. Ber. Bun. senges. physik. Chem., 59, 716 (1955)

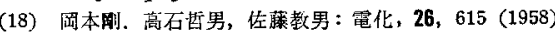

\title{
不銹鋼の分極特性亡不動態の安定性* \\ Polarization Characteristics and Stability of Passive State of Stainless Steels
}

岡本剛**, 永山政一***, 三谷幸男**, 石川達雄** Go OKamoto, Masaichi Nagayama, Yukio Mitani, Tatsuo IsHikawa

\section{1. 緒言}

不銹鋼が酎食合金として使用される主要な理由は、こ の合金が节酷な㧒食環境のもとでもきわめて自己不動䔮 化を起しやすい特性を有するからでする。しかし，元来 不銹銿の不動態には “安定”拓よび “準安定”の200 状態があり，後者の状態はある場合にははなはだ色険な ので，鋼がたとえ与方られた環境中で不動態をとったと しても，それがいずれの状態に該当するかを判別する必

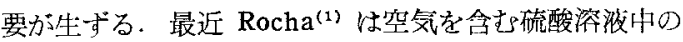
不銹鋼の分極曲線に濃度ならびに温度に忍じて第 1 図に 示すI，II 招よびIIIの3つの型が現われ，これらがそれ ぞれ“安定”, “隼安定”および “不安定不動態”に相当 することを退べ，分極曲線の型から不動態の安定度を判 定する方法を提案した. しかし Rocha 自身はいまだこ

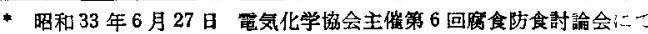
報告

** 北海道大学工学部（柇愰市北十二条西八丁目）

***同理学部(
}

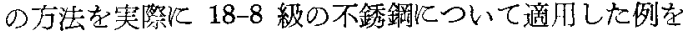

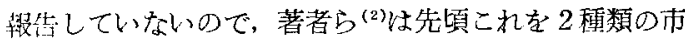

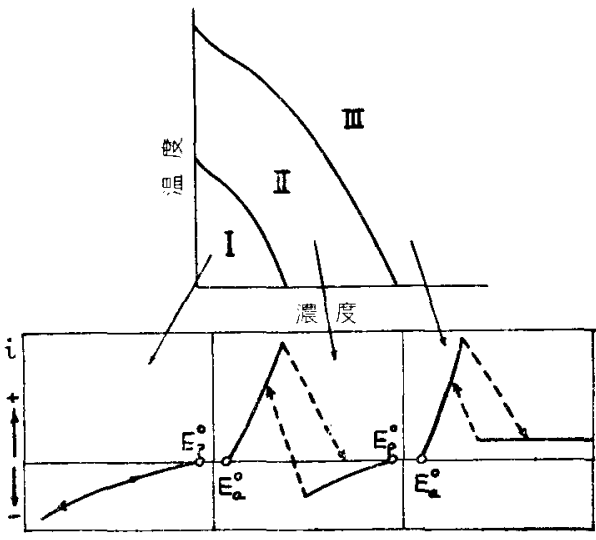

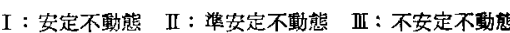

$E_{a}{ }^{\circ}:$ 活性驡に招ける自然電極電位

$E_{p}{ }^{\circ}$ : 不動態に教ける自然電極電位

第 1 図空気開放硫酸溶液中の不銹鋼の分極 曲楾の型と不動態の安定度との関係 
販不銹鋼に適用し硫酸の瀑度一温度図上の安定〜準安定 不動態の限界領域を推定するとともと従来の自然電極電 位の追跡(3)ならびに窝食測定(‘)飞上る判定法と比較検討 した. その結果, 従来の諸方法では最初の鋼表面処理方

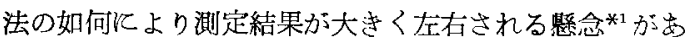
るが，この方法では定常的分極曲線を問題とするのて確 実に再現性のある結論に到達しうることが明らかになっ

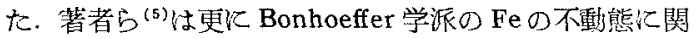
する基本的見解 ${ }^{(6)}$ V基ついて Rocha の方法の意義の解 䣋を試みた，すなおち，不銹銅のアノ一ド分極特性活“ 鋼の溶解反応” の分極曲線と “共存酸化削の還元反応” の分極曲線との合成飞よって決まること，又不動態の安 定度（自己不動態化能力）が活性態電位域江括る活分 担反応電流の相対的大いさに上って左右されることる推 論した.

本報飞批いて性，この推論飞基づき，5\% $\mathrm{H}_{2} \mathrm{SO}_{4}$ 溶液 中の数種の 18-8 級不銹鋼汇ついて各分担反応の分極曲 線を測定し温度ならびに溶存酸素の影響を検討した結果 を述へるる。

\section{2. 不銹鋼の分梗特性に対する推論}

空気な含む希硫酸中の不銹鋼面飞招いて問題の電位域 （活性態〜不動態）にわたって生起すると思われる篦極 反応は次の上うである。

$$
\begin{aligned}
& \text { [局部ソノード反応] } \\
& M \rightarrow M^{n+}+n e \quad \text { 銅溶解区灾 } \\
& \text { [局部カソード反度] }
\end{aligned}
$$

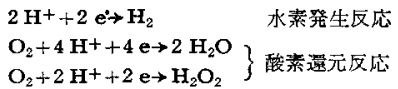

アノ一ド拾上びカソード反心の全電流( はそれ宅れの各分担反心の電流の総和伯当し，いすれ 子鋼の電位の関数之して変化する.

$$
\begin{aligned}
& \overleftarrow{i_{\mathrm{M}}}=\overleftarrow{\Sigma} i=\overleftarrow{i_{\mathrm{Fe}}}+\overleftarrow{i_{\mathrm{C}_{\mathrm{r}}}}+\overleftarrow{i_{\mathrm{N} \mathrm{i}}}+i_{\mathrm{M} 0} \\
& \overrightarrow{i_{\mathrm{r}}}=\vec{\Sigma} i=\vec{i}_{\mathrm{H}}+i_{0}
\end{aligned}
$$

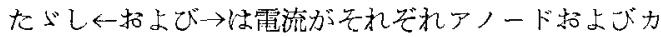
ソード方向でするとをを意味する。溶解晸流 飞還元電流 $\overrightarrow{i_{\mathrm{r}}}$ と電位との定常関係同一の電流軸を胡

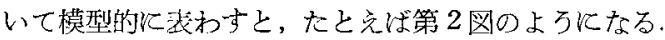

一般に $\overbrace{\mathrm{M}}$ 曲線には不動態化現象に関連して 3 つの電 位領域が存在する。すなわち $\mathrm{AB}$ 間 $(-0.3 \sim-0.2 \mathrm{~V} v \mathrm{~s}$. S.C.E.) は電流値が $\mathrm{mA}$ order で增減可活性態域, $\mathrm{BC}$ 間 $(-0.2 \sim+0.8 \mathrm{~V})$ は $10^{-3} \sim 10^{-5} \mathrm{~mA}$ の電流のき わめて小さい不動態域，C以上は再び電流の增大する過 不動態の領域である.これらの電位領域は一般鋼種， 酸の種類,濃度抽よび温度などによって変化するが,系を “18-8 級不銹鋼〜希硫酸”に限定した場合は変動の程度 があまり著しくないので一応概略の電位值を付したので

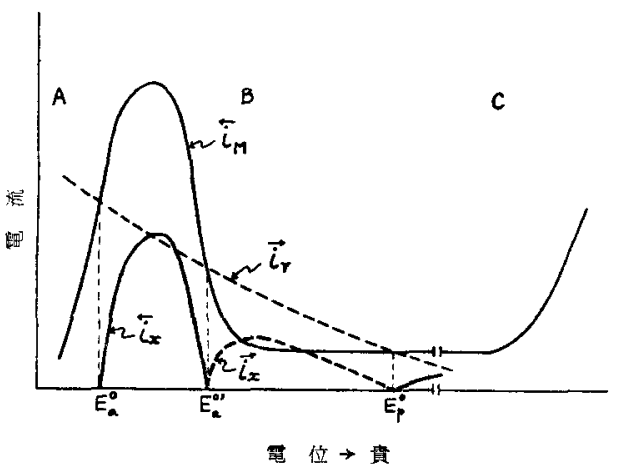

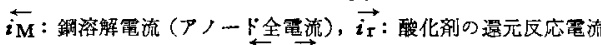
(全方ソード電流)， $i_{\mathrm{x}}\left(=\overleftarrow{i_{\mathrm{M}}}+\overrightarrow{i_{r}}\right) \cdot:$ 外部電流, $E_{a}{ }^{0}, E_{a}{ }^{\circ \prime}$ : 活 性態にお訬々自然電極電位, $E_{p}{ }^{\circ}$ : 不動態にお汁る自然電極電位 ……電流はアノード方向，…... 電流はカソード方向

筙 2 図 模型的に表わしたアノード敌よびカソード 分坦反応の分極曲線

引る，眮の各成分金属が溶出の際にとる価数は電位に応 こてて変わりろるが*2, 活性態域でね $\mathrm{Fe}^{2+}, \mathrm{Ni}^{2+}, \mathrm{Cr}^{2+}$ なは $\mathrm{Cr}^{3+}$ 和よび $\mathrm{Mo}^{3+}$ として溶出することが予想される*3.

これに刘し $\overrightarrow{i_{\mathrm{r}}}$ 曲線は，酸素逻元反底の平鮒雪位 $*^{* 4}$ (不

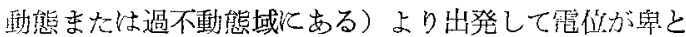
なるととるに单一に増大する. $i_{\mathrm{r}}$ の大いさ酸素濃度,カ キマゼ,酸漫度，鋼の表面状態などによって装化するが，

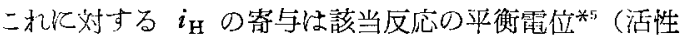

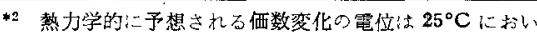

$\mathrm{Fe}^{2+}-\mathrm{Fe}+2 \mathrm{e}=0 \quad E_{h}=-0.441+0.0295 \log \left(\mathrm{Fe}^{2+}\right)$ $\mathrm{Fe}^{3+}-\mathrm{Fe}^{2+}+\mathrm{e}=0 \quad E_{h}=+0.746+0.0591 \log \left(\mathrm{Fe}^{3+} / \mathrm{Fe}^{2+}\right)$ $\mathrm{Cr}^{2+}-\mathrm{Cr}+2 \mathrm{e}=0 \quad E_{h}=-0.557+0.0295 \log \left(\mathrm{Cr}^{2+}\right)$ $\mathrm{Cr}^{3+}-\mathrm{Cr}^{2+}+\mathrm{e}=0 \quad E_{h}=-0.414+0.0591 \log \left(\mathrm{Cr}^{3}+/ \mathrm{Cr}^{2+}\right)$ $\mathrm{HCrO}_{4}^{-}+7 \mathrm{H}+-\mathrm{Cr}^{3+} \quad E_{h}=+1.300-0.138 \mathrm{pH}$ $-4 \mathrm{H}_{2} \mathrm{O}+3 \mathrm{e}=0 \quad+0.0197 \log \left[\left(\mathrm{HCrO}_{4}^{-}\right) /\left(\mathrm{Cr}^{3+}\right)\right]$ $\mathrm{Ni}^{2}-\mathrm{Ni}+2 \mathrm{e}=0 \quad E_{h}=-0.250+0.0295 \log \left(\mathrm{Ni}^{2+}\right)$ $\mathrm{Mo}^{3+}-\mathrm{Mo}+3 \mathrm{e}=0 \quad E_{h}=-0.200+0.0197 \log \left(\mathrm{Mo}^{3+}\right)$ $\mathrm{HMoO}_{4}^{2-}+7 \mathrm{H}^{+}-\mathrm{Mo}^{3+} E_{h}=0.390-0.1379 \mathrm{pH}$ $-4 \mathrm{H}_{2} \mathrm{O}+3 \mathrm{e}=0 \quad+0.0197 \log \left[\left(\mathrm{MoO}_{4}{ }^{2-}\right) /\left(\mathrm{Mo}^{3+}\right)\right]$

*3 $5 \% \mathrm{H}_{2} \mathrm{SO}_{4}$ 溶液 $(\mathrm{pH} \div 0)$ 中 $25^{\circ} \mathrm{C}$ に九いて熱力学的上予想され

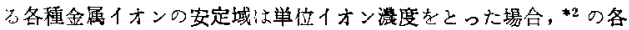
Nernst 式 $/ 25 \mathrm{Fe}^{2+\cdots \cdots} E_{h}=-0.44 \sim+0.75 \mathrm{~V}, \mathrm{Cr}^{2+\cdots \cdots-0.56}$ $\sim-0.41 \mathrm{~V}, \mathrm{Cr}^{3}+\ldots \ldots-0.41 \sim+1.30 \mathrm{~V}, \mathrm{Ni}^{2}+\ldots \ldots, 0.25 \mathrm{~V} \alpha^{2}$

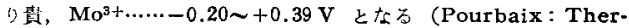
modynamics of Dilute Aqueous Solution (1949) 参照). 18-8 不綉鋼の活性態域は啭ね $-0.4 \sim-0.2 \mathrm{~V}$ vs. S.C.E. $\left(E_{h}=\right.$ $-0.15 \sim+0.05)$ にあるから $\mathbf{M o}^{3+}$ が安定である. $\mathrm{Fe}^{2+}, \mathrm{Ni}^{2+}$ の溶出心諸研究者の串貺結果か

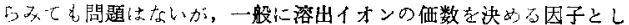

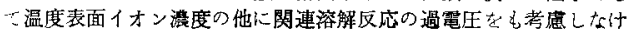
れはならないので，Crについては $\mathrm{Cr}^{2+}, \mathrm{Cr}^{3+}$ のいずれの経路を とるか有断できない. Heumann (Z. Elektrochem., 62, 745 $(1958)$ ) は維 $\mathrm{Cr} の \mathrm{H}_{2} \mathrm{SO}_{4}$ 溶液中の活性態 $\left(E_{h} \doteqdot-0.5 \sim-0.3\right)$ に执いて $\mathrm{Cr}^{2+}$ としての容出を仮定している. 18-8 不銹鋼につい て銅の全溶出量より $i \mathrm{M}$ を推定する埸合，いずれの洒数をとるとし ても 一忘 $\mathrm{Cr}^{2+}$ とての溶解老仮定した。

.4 $\mathrm{O}_{2}+4 \mathrm{H}+-2 \mathrm{H}_{2} \mathrm{O}+4 \mathrm{e}=0 \quad E_{h}=+1.228-0.0591 \mathrm{pH}$ $+0.0148 P_{0}$ $\mathrm{O}_{2}+2 \mathrm{H}^{+}-\mathrm{H}_{2} \mathrm{O}_{2}+2 \mathrm{e}=0 \quad E_{h}=+0.680-0.0591 \mathrm{pH}$ $+0.0295 \mathrm{PO}_{2}$ $-0.0295 \log \left(\mathrm{H}_{2} \mathrm{O}_{2}\right)$

*5 $2 \mathbf{H}^{+}-\mathrm{H}_{2}+2 \mathrm{e}=0 \quad E_{h}=-0.0591 \mathrm{pH}$ 
第 1 表試料不銹鋼の分析組成と形状

\begin{tabular}{|c|c|c|c|c|c|c|c|c|c|c|c|}
\hline No. & AISI 型 & C & $\mathrm{Si}$ & $\mathbf{M n}$ & $\mathbf{P}$ & $\mathbf{S}$ & $\mathrm{Cu}$ & $\mathrm{Ni}$ & $\mathrm{Cr}$ & Mo & 形状 \\
\hline 1 & - & 0.05 & 0.52 & 1.65 & 0.12 & 0.022 & 0.10 & 15.97 & 17.25 & tr & 板状 \\
\hline 2 & - & 0.05 & 0.50 & 1.58 & 0.15 & 0.022 & 0.10 & 15.64 & 16.95 & 2.16 & $2 \mathrm{~mm}$ \\
\hline 3 & - & 0.05 & 0.50 & 1.48 & 0.15 & 0.022 & 0.08 & 15.78 & 17.00 & 4.01 & 厚さ \\
\hline 4 & 304 & 0.07 & 0.62 & 1.07 & 0.033 & 0.026 & - & 8.79 & 18.65 & tr & 線状 \\
\hline 5 & 316 & 0.06 & 0.91 & 1.58 & 0.025 & 0.010 & - & 12.64 & 17.78 & 2.35 & $\phi \Rightarrow 3 \mathrm{~mm}$ \\
\hline
\end{tabular}

熱処理: $1050^{\circ} \mathrm{C} \times 15 \mathrm{~min}$, 水冾

態域にある) より卑電位の領域でのみ起こる.

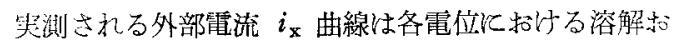
よび遙元電流の合成したるのに相当するはずでせる。

$$
i_{\mathrm{x}}=\overleftrightarrow{i_{\mathrm{M}}}+\overrightarrow{i_{\mathrm{r}}}
$$

$i_{\mathrm{M}}, i_{\mathrm{r}}$ 曲線の相対的位置が第 2 図のような埸命には,

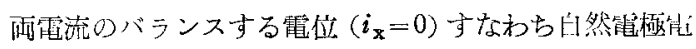
位が 3 力㸝 $\left(E_{a}{ }^{\circ}, E_{a}{ }^{\circ}\right.$ 特よび $\left.E_{p}{ }^{\circ}\right)$ 存在し*6, そのうも

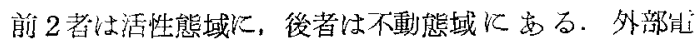

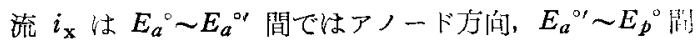
ではカソード方向となる (Rocha 曲線 II)．この上万た

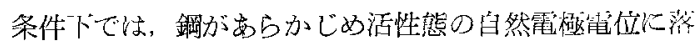
着け将，その状態を長く保持して自己不動態化在起さな

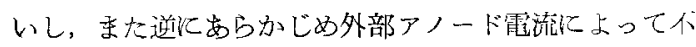

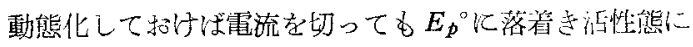
はもどらない，すなわち準安定不動態該当する。これ 飞対し問题の全霆位域にわたり $i_{\mathrm{r}}>i_{\mathrm{M}}$ 特尗び $i_{\mathrm{r}}<i_{\mathrm{M}}$

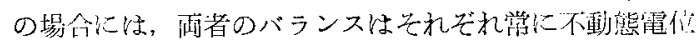

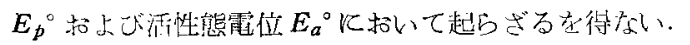

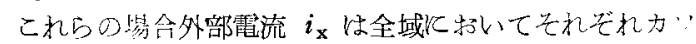

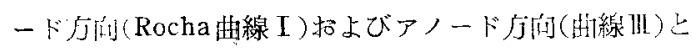

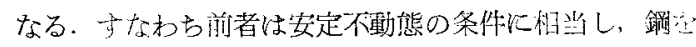

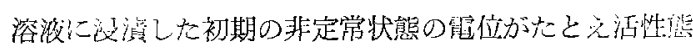

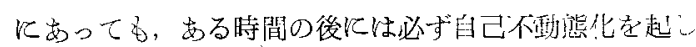

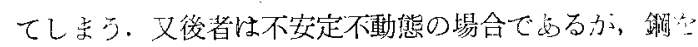

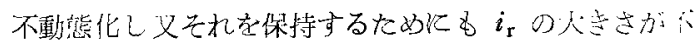

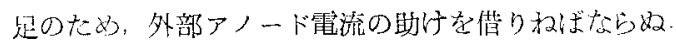

以上U上万溶存酸化剂(この場合的 $\mathrm{O}_{2}$ 挌上び $\mathrm{H}^{-}$

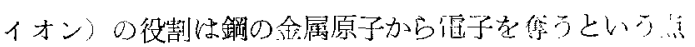

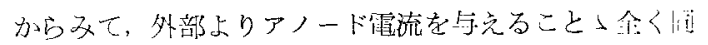

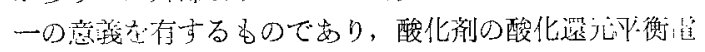

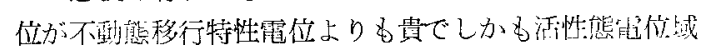
での邀元没速度が十分大きければ，外部上りアノード 電流を、をえなくてる銅は不動態化しこれを維持できるり である.

以上の䀯解住 Franck, Weil (7) 加 $\mathrm{Fe}-\mathrm{H}_{2} \mathrm{SO}_{4}(1 \mathrm{~N}$ -

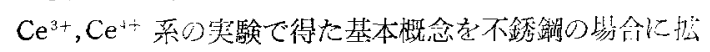
張適用したるのであるが，最近著者らと類似の見解が他

*6 多人研究者立と文は Racha (1) (3)；C. Carius (Archiv. Eisenhïttenw., 26,769 (1955)) は $E_{a}{ }^{\circ}$ 公不動热の话化化车

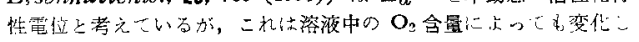
;るのて敞密には特性電位とはいいがたい。
の二，三の研究者(8)(9) とよっても提出されている. しか しこの敇の見解が果して不銹鋼の場合に適用しうるかど

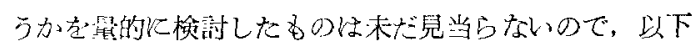
次の广針にって果験を行うことつした。

(1) 自動定電位装置を网いて鋼を活性態の一定電位に 保持し，溶难の分析炕よって溶解電流 $\overleftarrow{i_{\mathrm{M}}}$ 曲線を求め, これに対する深液の $\mathrm{O}_{2}$ 含量怙よびカキマゼの影響を調

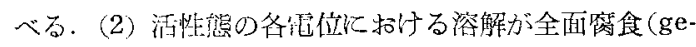
neral corrosion) の性格のものであるかどうか子溶液中

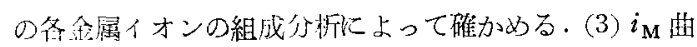

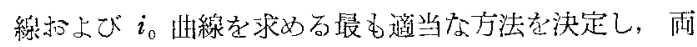

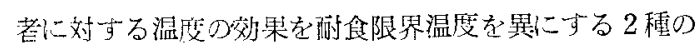
不鋢鏩について比較する。

\section{3. 実 験 方 法}

（1）試料および溶夜 不鉟鎆陚料の組成招よび形状

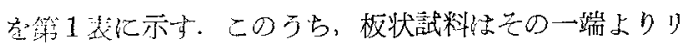
一妾とり理远樹脂（丸本製エポキシ系レジン）中に埋

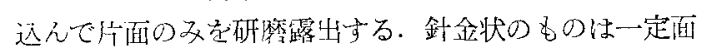

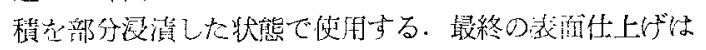
0/4 エメリ一紬にて行い, ベンゼンで脱脂後使月直前に

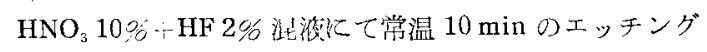
䘮行い水洗する。

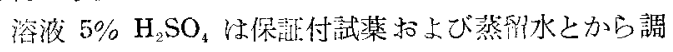
繁した。

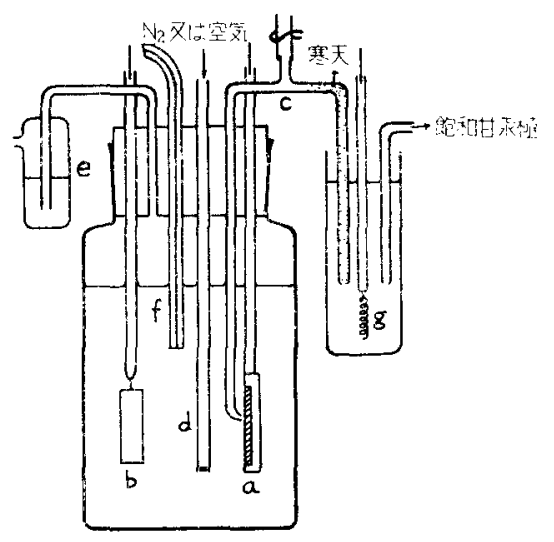

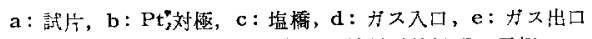

$\mathrm{f}$ : 浴液採取打毛細管, $\mathrm{g}$ : 予借電解精赘用外部 $\mathbf{P t}$ 奄婳

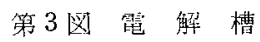




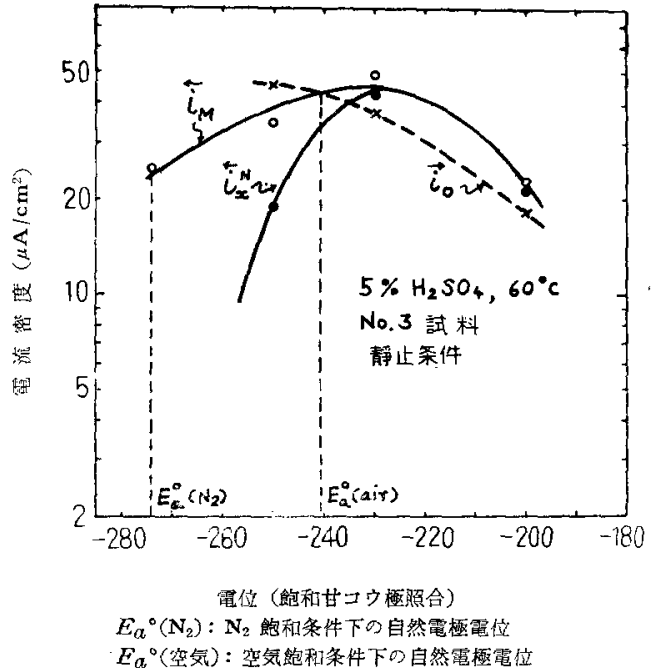

第 5 図 活性態電位の No. 3 試料の $i_{\mathrm{M}}$ と $i_{\mathrm{x}} \mathrm{N}$ との比較

第 3 翡 $i_{\mathrm{M}}$ 和よび $i_{\mathrm{x}}$ の䨌位化よる变化 (No. 3 試料, $5 \% \mathrm{H}_{2} \mathrm{SO}_{4}, 60^{\circ} \mathrm{C}$ )

\begin{tabular}{|c|c|c|c|c|c|}
\hline \multirow{2}{*}{$\begin{array}{c}E \\
m V \\
\text { (vs.S.C.E.) }\end{array}$} & $V_{M}$ & $i \mathrm{M}$ & $i_{\mathrm{x}}{ }^{\mathrm{N}}$ & (静正) & (静正) \\
\hline & $\mathrm{g} / \mathrm{m}^{2} \cdot \mathrm{h}$ & $\mu \mathrm{A} / \mathrm{cm}^{2}$ & $\mu \mathrm{A} / \mathrm{cm}^{2}$ & $\mu \mathrm{A} / \mathrm{cm}^{2}$ & $\| \mathrm{A} / \mathrm{cm}^{2}$ \\
\hline-200 & 0.222 & +21.5 & +22.9 & +4.8 & -18.1 \\
\hline-230 & 0.467 & +49.7 & +42.4 & +4.9 & -37.5 \\
\hline-250 & 0.354 & +34.6 & +18.8 & -26.2 & -45.0 \\
\hline-274 & 0.259 & +25.3 & 0 & - & - \\
\hline
\end{tabular}

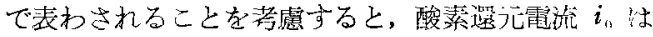

$$
\overrightarrow{i_{0}}=\left(\overrightarrow{i_{\mathrm{r}}}-\overrightarrow{i_{\mathrm{H}}}\right)=i_{\mathrm{X}}-{\overleftarrow{i_{\mathrm{X}}}}^{N}
$$

として算出されることがわかる。

以上の結果から，与光口れた空気䭂和硫酸溶液中の不 銹鋼について次のようにして各分担反灾霓流を求めれば よい、すなわ方，(イ） $i_{\mathrm{M}}$ 曲線を求めるに恪電位儿招

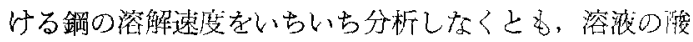

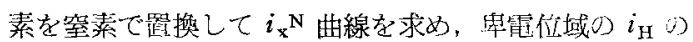

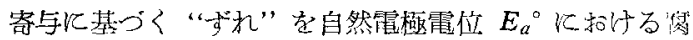
食電流の测定によって補正する。（口）このらにして 求めた $i_{\mathrm{M}}$. 曲線と空気飽和条件の $i_{\mathrm{x}}$ 曲線とから全力り 一ド反広琵流曲線すなわち $\vec{i}_{\mathrm{r}}=\left(\overrightarrow{i_{0}}+\overrightarrow{i_{\mathrm{H}}}\right)$ 曲線が得らわる

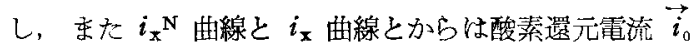
曲線力゙求められる。

実験 2. 活性稳における 全面腐食性の検討 上述 の夷験結果の解釈では鋼の全面㧒食性を仮定しているの で，乙れを確かめる必要がある.古くMüller (12) 硫酸

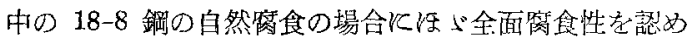
ているが，活性態の全電位域林たて検討を加光たる のはいまだ見当らない，そこで武料 No. 1, No. 2 捛よび No. 3 の各一定分極電位に扣いて第 3 図达べた一速の

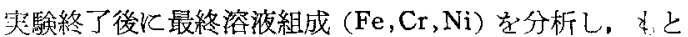

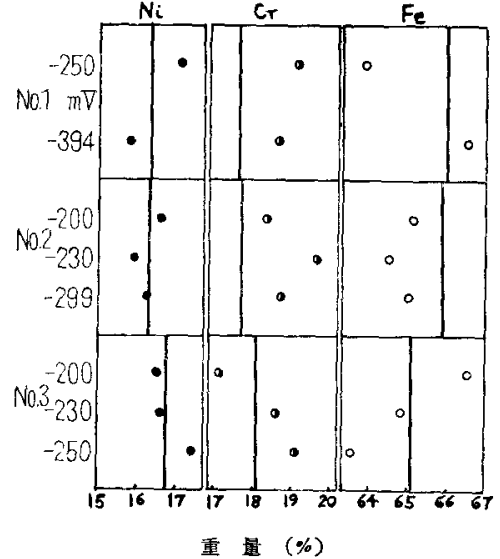

第 6 园 No. 1 3 試料の定電位溶解実騟终了 後の溶液分析組成と鋼組成々の比較

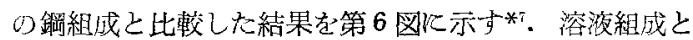

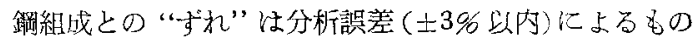
ではなく，銅面が完全に均一なオーステナイト椙 ( 相) ではなくこれと多数の異種の相 ( $\delta$ 相， $\sigma$ 相など)が混在

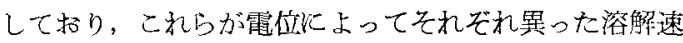

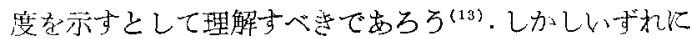
してもこの程度の小さな“ずれ”は $V_{\mathrm{M}}$ なた $i_{\mathrm{M}}$ 值

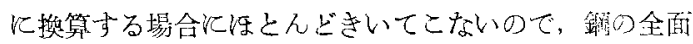

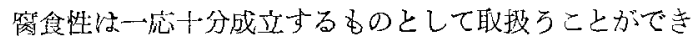
b.

実験 3. $i_{\mathrm{M}}$ およひ $i_{\mathrm{r}}$ の鋼種による变化 智磁 1 の絬果から推論された方法比より, 試料 No. $4(18 \mathrm{Cr}$ -

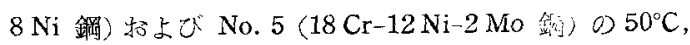
$5 \% \mathrm{H}_{2} \mathrm{SO}_{4}$ の条件下に和ける $i_{\mathrm{M}}$ 扣よび $i_{\mathrm{r}}$ 画線学求め て比較した.すなわちまず窒素飽和条件下で $i_{\mathrm{x}}{ }^{\mathrm{N}}$ 曲線を

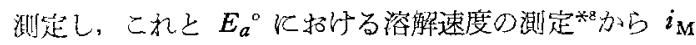

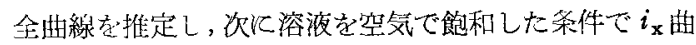
楾を求め唡者の合成加ら $i_{r}$ を決定した，得られた結果

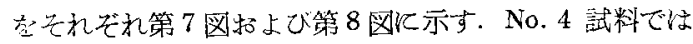
$i_{M}$ 最大の電位域に和いて $\left|i_{M}\right|>\left|i_{x}\right|$ であるから準安定 不動態の場合飞相当し，活性態域火200安定な自然電 極雷位 $E_{a}{ }^{\circ}, E_{a}{ }^{\circ}$ が明らが存在する。これに刘し No. 5

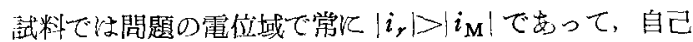
不動態化能力を有する缶定不動態の場合炕相当すること がわかる。

Mo 杂合李ないNo. 4 試料では No. 5 試料比べ $i_{M}$ の值が全電位域にわたって著しく大きく，公素ふん囲気 中の自然電極電位呿上び不動態移行電位がそれそれ若十

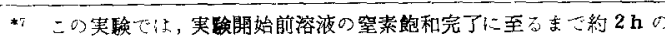
目然腐食過程ボ先行しているので全腐食量中心法これも含まれてい $\therefore$.

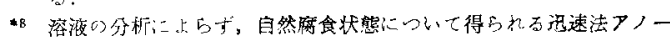

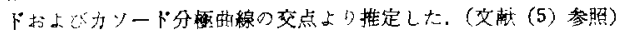




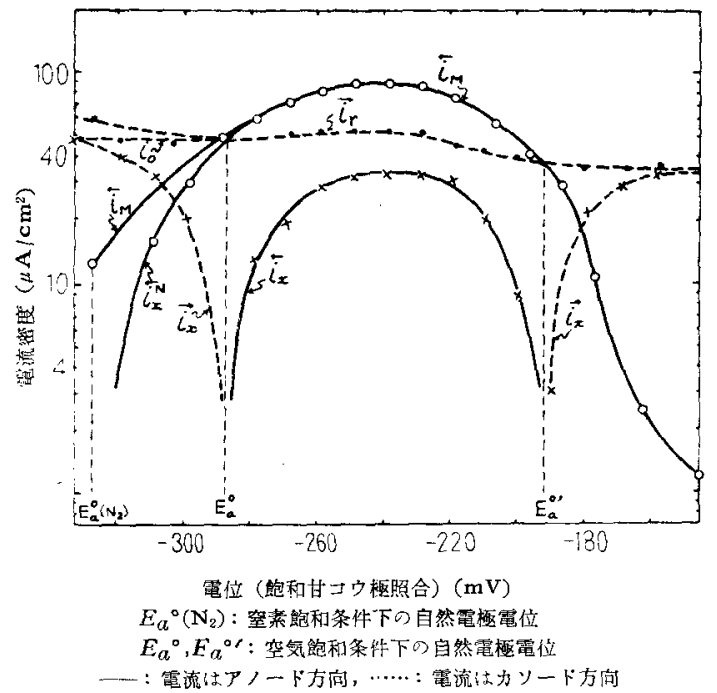

第 7 图 $5 \% \mathrm{H}_{2} \mathrm{SO}_{4}\left(50^{\circ} \mathrm{C}\right)$ 中飞和ける No. 4 䧼 料の分担反心分極曲線

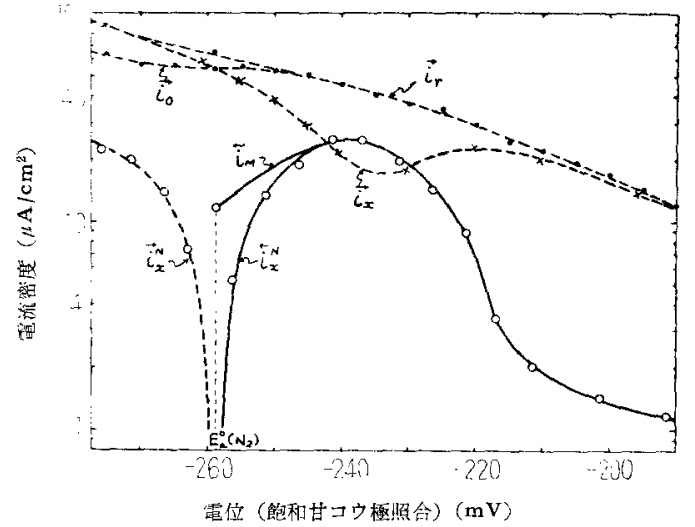

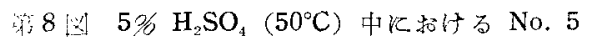
誈料口分程反灾分極曲線

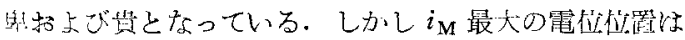

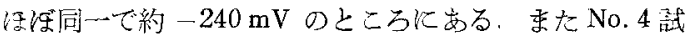

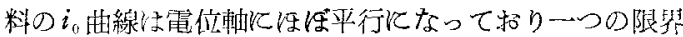

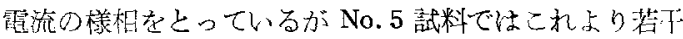
傾斜が急であって， $i_{\mathrm{M}}$ 最大の位置の $i_{0}$ 值河程度の做

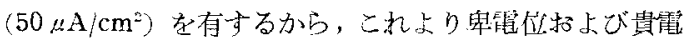
位域では $i_{\mathrm{r}}$ 傎が No.4 䇅料のそれに比べてそれでれ大 抢よび小よなっている。このように $i_{\mathrm{r}}$ 曲線の傾斜は一

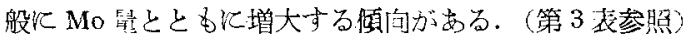

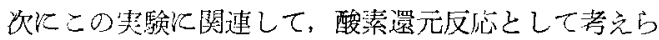
れる2種の反応中いずれが優梦に起っているが調へる ため，No. 4 試料の然気飽和静止条件下， $i_{\mathrm{M}}$ 最大の䨌 位に招いて $66 \mathrm{ppm} の \mathrm{H}_{2} \mathrm{O}_{2}$ を添加したとこる $i_{0}$ 偡は $50 \rightarrow 208 \mu \mathrm{A} / \mathrm{cm}^{2}$ と著しい增大を示した.この結果より $i_{0}$ のかなりの部分が $\mathrm{O}_{2}+4 \mathrm{H}^{+}+4 \mathrm{e} \rightarrow 2 \mathrm{H}_{2} \mathrm{O}$ なるいわゆ
る4電子反応で与められていることがわかる。

実験 4. $i_{\mathrm{M}}$ および $i_{0}$ に対する温度ならひにカキマ ゼの影锌 上述のように不動熊の安定度の決定には， $i_{M}$ 最大の電位位置飞招ける $i_{\mathrm{M}}$ と $i_{\mathrm{r}}\left(\fallingdotseq i_{0}\right)$ の相対的大以 さが問題となるので， $5 \% \mathrm{H}_{2} \mathrm{SO}_{4}$ 中の No. 4 格よび 5 の二種の武料について種々の温度に猢方雨者の関係を 調べてみた，その結果を第 9 図に示す、 $i_{M}$ 最大の電位 位置は温度によってほ上んど変化しない， $i_{\mathrm{M}}$ が $i_{\mathrm{r}}$ を㥄 翵して自己不動態化能力を失万限界温度 $T l$ は No. 4 抽

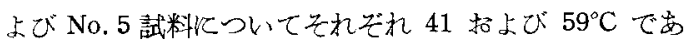

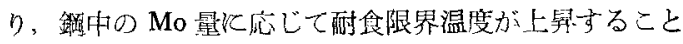
が加かる。

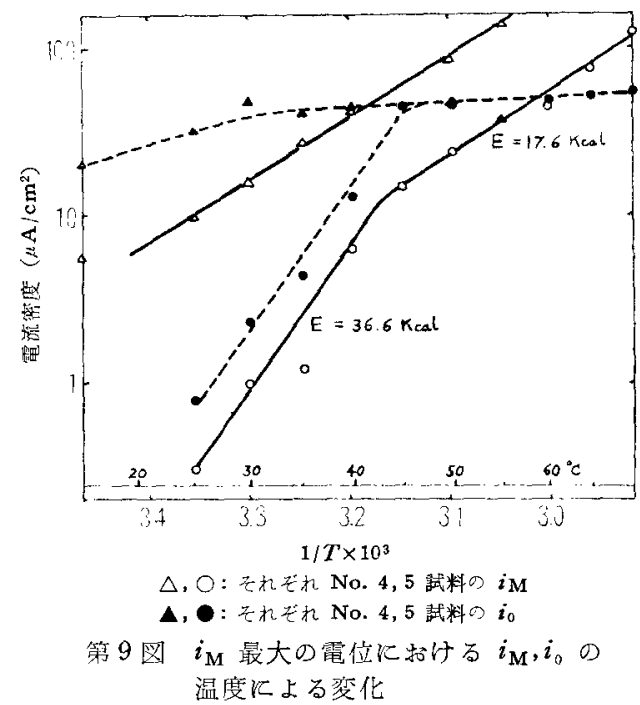

No. 5 辞粗の $i_{M}$ 值以どの上万な温度に和いても常飞

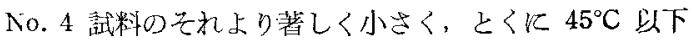
で温度低下ととるにその差がはなはだしくなる。 の温度变化より求如られる溶解反応の見掛けの活性化工 京ルギー惊 No. 4 試料の $25 \sim 55^{\circ} \mathrm{C}$ 打よび No. 5 試料の $45 \sim 70^{\circ} \mathrm{C}$ ではと本に $17.6 \mathrm{kcal}$, No. 5 試料の $45^{\circ} \mathrm{C}$ 以 トではにれぶ $36.6 \mathrm{kcal}$ となる。 また No. 4 試料の $i_{0}$ 倠は温度に占る変化がきわめて小さく，とくに $30^{\circ} \mathrm{C}$ を 起光ると㭱とんど温度依存性を示さなくなる（兒卦けの 淮性化エネルギー $1.2 \mathrm{kcal}$ )。これは No. 5 試料の $45^{\circ} \mathrm{C}$ 以上に括いて舟同様てめって，しか子その得 $50 \mu \mathrm{A} / \mathrm{cm}^{2}$ 以雨辣料儿其通している. No. 5 試料の $45^{\circ} \mathrm{C}$ 以下の低 温では温度依存性が現われ見掛けの活性化エネルギーは $i_{\mathrm{M}}$ と同様の值約 $36 \mathrm{kcal}$ となる.

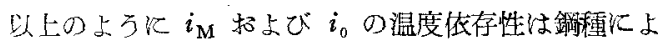
ってもはなはだ様子を異にして特り，与光られた鋼のあ

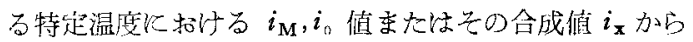
その柎食限界温㹂を推定することはできない，

次に $i_{\mathrm{M}}$ 如よび $i_{0}$ のカキマゼ依存性を各温度に拾い 
て定性的に調べた・すなわら，まず窒素らん国気中で窒

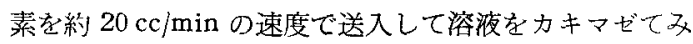
たが， $i_{\mathbf{x}} \mathrm{N}\left(\doteqdot i_{M}\right)$ 值にはいずれの温度に招いてもほとん ど変化がなかった．この事実と実験 1 の第 4 図の結果と をあわせ考虑すれば，溶解反応電流がはとんとカキマゼ に依存しないことは明らかであり，あ死種の藏面反応過 程により律速されるものと推定される。

酸素還元電流 $i_{0}$ は $i_{\mathrm{M}}$ と異って著しいカキマゼ依存 性を有し，たと充ば $20 \mathrm{cc} / \mathrm{min}$ の空気送人により $2 \sim 4$

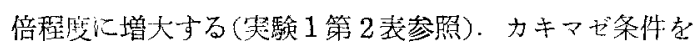
変化した際の再流の時間的変化の様子は，限留温度 $T_{l}$

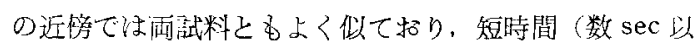
内）の大幅な変化の後比較的功くり（数 $\min$ 和㾏）上 した変化が和こる. No. 5 武料の低温域战什る $i_{0}$ の小

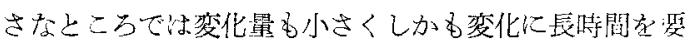

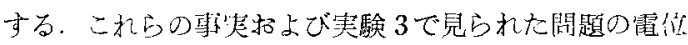

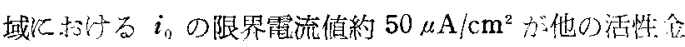

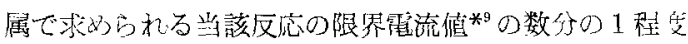

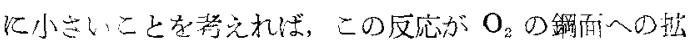

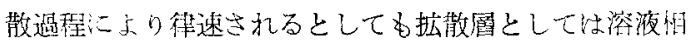

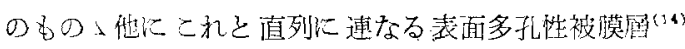

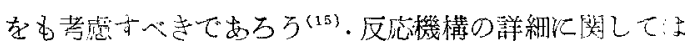
今後な和多くの恰封を要するが，以上のように $i_{\mathrm{M}}$ 以比

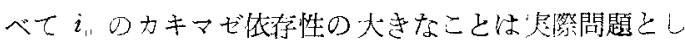

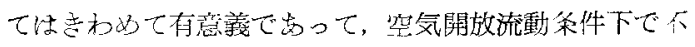

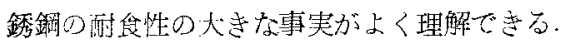

\section{5. 要 約}

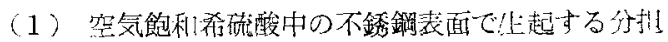

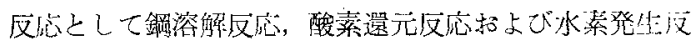

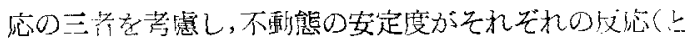

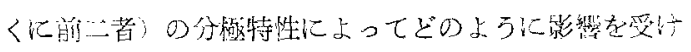

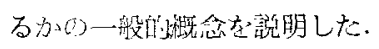

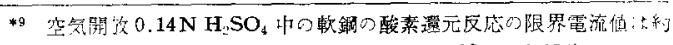
$300 \mu \mathrm{A} / \mathrm{cm}^{2}$ (圆本，沓山，久保因：雨化，22，8（1954）
（2）鋼溶解反応力酸素還元反応の存在とは無関係に 進行寸る事䒠に基き，各分担反店の分極曲線を求める最 も妥当な方法学提案した。

（3）定電位電解装置老用w，5\% $\mathrm{H}_{2} \mathrm{SO}_{4}\left(50^{\circ} \mathrm{C}\right)$ 中，

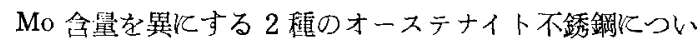
て各分担反応の分極曲線を垁測し，酸素還元反応曲線仙 活性㮩電位域でほ ること，Mo 添加炕ょる不動態の安定度の増大は主に鍮

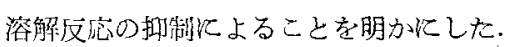

(4) $5 \% \mathrm{H}_{2} \mathrm{SO}_{4}$ 中, 活性態の鋼溶解速度最大の電位 (-240 mV vs. S.C.E.) は温度和よびカキマゼによって

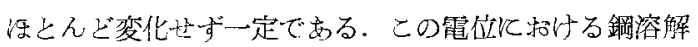

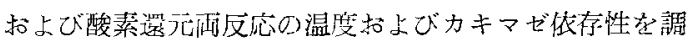

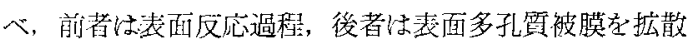
圆の一部として含む酸素抾散過程に上りそれでれ律速さ れることが判明した。

本研究は炤和 32 年度文部省科学研究費(化学促進) の愽助飞よる。

\section{文献}

(1) H.J, Rocha: Handbuch der Sonderstahlkunde (Hoydremont) Band I, p. 758 (1956)

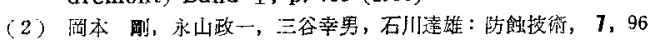
(1958)

(3) H.J. Rocha, G. Lennartz: Arch. Eisenhüttenw., 26, 117 (1955)

(4) E.H. Phelps, D.C. Vreeland : Conosion, 13, $619 \mathrm{t}$ (1957)

(5) 烊本甽, 永山政一: 防蝕技術, 7, 194 (1958)

(6) K.F. Bonhoeffer: Z. Metallk., 44, 77 (1953)

(7) U.F. Franck, K. Weil : Z. Elktrochem., 56, 814 (1952)

(8) C. Edeleanu: J. Iron \& Steel Inst., 188, 122 (1958)

(9) W. Gödecke: Wer kst. u. Kon rosion, 8, 580 (1957)

(10) E.B. Sandell : Colorinetric Determination of Traces of Metals, 2 nd Ed. (1950)

（11）池上卓稳，神菻大浐：分析化学，1，73(1952)

(12) W.J. Miller : Z. Elektrochem., 41, 774 (1935)

(13) C. Edeleanu: J. Iron \& Steel Inst., 185, 482 (1957)

(14) W.J. Muller : Die Bedeckungstheorie der Passivität der Metalle und ihre experimentere Begründung (1934)

（15）阅本剧, 久保田宏, 永山政一：電化，22，213（1954） 